2021, volume 10, issue 3

Tiruneh, D.T. (2021). The Perspective of Corporate Governance on the Interactions of Internal Audit with Management and its Impact on the Internal -External Audit Linkages. Copernican Journal of Finance \& Accounting, 10(3), 51-70. http://dx.doi.org/10.12775/CJFA.2021.011

\title{
THE PERSPECTIVE OF CORPORATE GOVERNANCE ON THE INTERACTIONS OF INTERNAL AUDIT WITH MANAGEMENT AND ITS IMPACT ON THE INTERNAL - EXTERNAL AUDIT LINKAGES
}

Keywords: management, external audit, internal audit, corporate governance, internal-external audit linkages, Ethiopia.

J E L Classification: M10, M12, M14, M16, M42, L20.

Abstract: Literatures based on developed countries suggest an interaction of internal audit with management has impact on the internal-external audit linkages and the interactions and linkages have their own contribution toward the realization of good corporate governance. Nevertheless, these interactions have not been sufficiently explored in developing countries such as Ethiopia.

This quantitative research examines in the form of explanatory study the interaction of internal audit with management and its impact on the internal- external audit linkages in Ethiopia. By doing so, it explained the causal relationship between variables through hypothesis testing. The research method of this study was a constructed questionnaire, which was sent to companies and to the 100 top management, internal auditors, and external auditors in Ethiopia.

As it has been examined, existing findings suggest that organizations can enhance corporate governance's effectiveness by strengthening the interactions of internal

Date of submission: March 26,2021; date of acceptance: May 2,2021.

* Contact information: dawittadesse9053@yahoo.com, GAMBY Medical and Business College and Addis Ababa University School of Commerce, Ethiopia and Managing Partner of Lead Plus consulting, Ethiopia, phone: 251911109648; ORCID ID: https://orcid.org/0000-0001-5885-6539. 
audit with management and in the meantime as the result of this impact by upgrading the internal-external audit linkages. In line with this, the results indicate interactions of internal audit with management depend on the level of the result of internal audits' effectiveness, as the result, it positively moderates the internal-external audit linkages.

\section{IIIINTRODUCTION}

It has been broadly perceived that the job of the internal auditor turns out to be progressively more significant as far as making great corporate governance structures (Allegrini, D’Onza, Paape, Melville and Sarens, 2006; Carcello, Hermanson \& Raghunandan, 2005; Nagy \& Cenker, 2002). In such manner, internal auditor relationship with directorate (or managment) is viewed as of essential significance to accomplish sound corporate governance (Maletta, 1993; Messier \& Schneider, 1988). For Renard (2006), such an association permits internal auditors to completely practice their job as the executive's advisors, communicating with senior management's and all degrees of the management's.

As per the organization's hypothesis (Adams, 1994), internal auditor report shows up as a component to control the conduct of the supervisors if managements have completely regarded all their legally binding commitments. Rezaee (1996) expressed the burden of this association as « cop of the management's ", which doesn't completely mirror its actual part during the time spent danger the executives, creation and advancement. Then again Mihret and Woldeyohannis (2008), Mihret and Yismaw (2007), Roth (2000) express that internal auditor report adequacy as estimated by the management's acknowledgment and execution of internal auditors discoveries and suggestions may affect on external auditor dependence on internal audit work. Corporate governance is required to improve the part of the internal auditor; and simultaneously, the internal auditor likewise gives advantages to the external auditors (Holm \& Laursen, 2007). Meanwhile, collaboration among internal and external auditors would be one method of making the worldwide auditors measure more productive and powerful (Felix, Gramling \& Maletta 1998, 2001; Moore \& Hodgson, 1993). Coordination of internal and external audit reports, has gotten impressive consideration particularly in the course of the most recent decade because of the agreement that hearty corporate governance frameworks help limit the staggering effect of corporate breakdown (Rusak \& Johnson, 2007).

In such manner, this examination is started to embrace this investigation in light of a few reasons. In the first place, research has been done on depend- 
ence of external auditors on internal audit work: a corporate governance point of view by the instance of firms in growing yet next to no is thought about the communications of internal audit with the management's and its effect on the internal and external audit linkages in developing nations such as Ethiopia (Mihret \& Admassu, 2011). In the meantime, to the knowledge of this article writer, in this topic there is no single study found in Ethiopia. In this regard, this research will fill the literature review gap. Second, this exploration on these associations will give some important experiences on the matter.

The exploration directed by Endaya and Hanefah (2013) states that the attributes of internal auditor reports directed by the management's backing can improve the viability of internal audit. The executives backing can be found in a few structures, for example, helping the group in dealing with snags, showing obligation to work, and empowering subordinates (Kandelousi, 2011). The management's support is given by utilizing able internal auditor report staff, creating vocation ways for internal auditors staff, and giving authoritative freedom to internal audit works (Cohen \& Sayag, 2010).

What makes auditors program properly functional is stated as freedom brought about by the management and the shortfall of pressing factor coming from the auditee (Van Peursem, 2005). This is an experimental proof that authoritative autonomy influences efficiency (Cohen \& Sayag, 2010; George, Theofanis \& Konstantinos, 2015; Badara, 2015). Autonomy slows down the internal and audit execution in developing nations (Alzeban \& Gwilliam, 2014). In accordance with this, Arens, Elder and Beasley (2011, p. 43) expressed proficient expertise controlled by the auditors in leading auditors offered excellent types of assistance and can be represented on the grounds that the capacity of expert internal auditor reports isn't just to discover shortcomings in internal control, yet additionally to uncover the auditors discoveries and expect them later on and make upgrades. Auditors professionalism has an impact towards the adequacy of internal audits which have been demonstrated by Tackie, Marfo-Yiadom and Achina (2016) in the neighborhood government in Ghana.

Generally speaking regarding these outcomes, the internal auditors work turns out to be progressively more significant as far as making great corporate governance structures (Allegrini et al., 2006; Carcello et al., 2005; Nagy \& Cenker, 2002). In reference to Sarens (2009), the ability of the internal audit to impact the nature of corporate governance determines the viability of internal auditor's report. This examination is in agreement with the exploration conducted by Mihret and Yismaw (2007). 
In this respect, therefore, top managements lessen their level of responsibility based on the outcome of external auditors findings. Following the discussions done so far, the hypothesis is stated here in detail.

$\mathrm{H}_{1}$ : Internal-external auditors' linkages rely upon the associations of internal audit with the management's as the consequence of the management's support toward decidedly directs the impact of positive hierarchical autonomy towards the viability of internal audits.

$\mathrm{H}_{2}$ : Internal-external auditors linkages rely upon the associations of internal auditor report with the executives as the aftereffect of the management's support toward emphatically directs the impact of positive auditors' demonstrable skill towards the viability of internal audits.

In accordance with H1, Alzeban and Gwilliam (2014) express that management's backing can likewise be through improving connection between internal auditors and external auditors. Closeness Mihret and Woldeyohannis (2008), Mihret and Yismaw (2007), Roth (2000) stated that internal audit viability as estimated by the management's acknowledgment and execution of internal auditor report discoveries and proposals may effect on external auditors' dependence on internal auditors work. Thus, more significant levels of acknowledgment of internal audit suggestions by the management's may prompt more elevated levels of external auditor dependence than a circumstance where internal auditor report is less powerful. Predictable with the above investigations Al-Twaijry, Brierley and Gwilliam (2004), Felix et al. (2001) stated, internal and external auditors linkages via the last's dependence of the previous' work is useful to associations and hence sheets of chiefs and the executives are probably going to support such linkages.

Additionally, Alzeban and Gwilliam (2014), Badara and Saidin (2014), Shohiha (2017) all confirmed that the coordination among internal and external auditors is significant for the advantages of auditors of associations and outer partners. . The connection among internal and external auditors which impacts the adequacy has been exactly demonstrated. This coordination and joint effort is done consistently to get ideal advantages for the regular interests and objectives. The capacity to encourage great associations with external auditors directed by internal examiners keeps up the viability of hierarchical management's (Gramling, Maletta, Schneider \& Church, 2004). In view of the clarification of the investigations, the hypothesis is planned as follows: 
$\mathrm{H}_{3}$ : Internal-external auditors' linkages rely upon top management's support as the consequence of the management's acknowledgment and execution of internal audit discoveries and proposals technique.

\section{METHODOLOGY}

To gather data, in a proper manner for a descriptive research, a survey questionnaire is utilized (Alleyne and Devonish, 2006; Paper et al., 2003).The survey was organized in respect with the exploration speculations and the applicable writing audit. Subsequently, representativeness of the example to the population was not the objective of the investigation; the endeavor rather has been made to guarantee legitimacy of the information by applying purposive inspecting (Oppenheim, 1992).

Right off the bat, questions are chosen basically by three studies that inspected comparative examination field: Bota-Avram and Palfi (2009), Mihret and Yismaw (2007), Cohen and Sayag (2010) and Alzeban and Gwilliam (2014). The inquiries at long last remembered for the poll are considered as more important with the current investigation just as more huge as to their substance. The polls involve 49 inquiries altogether, which are independently ready for the management, internal and external auditors. These polls are at long last converged for compelling information introduction.

The information in this exploration was dissected utilizing Partial Least Square (PLS) to test a few factors and the directing impacts. A 5-point Likerttype scale was utilized to quantify, directors and external and internal auditors' mentalities as these factors are developed. Descriptors and comparing mathematical codes: 'Firmly Agree' [5], 'Concur' [4], 'Impartial' [3], 'Dissent' [2], and 'Emphatically Disagree' [1] and Always (5) Often (4) Sometimes (3) Seldom (2) Never (1) were given as reaction alternatives. In such an action, it is important to obviously show the disposition object, about which feelings are looked for (Bradburn, Sudman, \& Wansink, 2004). Hence, we obviously expressed in the guidelines that the respondents were required to give suppositions on the proclamations as applied to their customers that keep up internal auditors divisions. All things were emphatically expressed ideas utilized as markers of the factors. 


\section{MODEL}

The research method of this study was a constructed questionnaire, which was sent to companies and to the 100 top management, internal auditors, and external auditors in Ethiopia. Taking into consideration the above literature and hypothesis development the following five variables are selected to be examined in the present research. These variables are important with the current investigation. The first is "Interactions of internal audit with management's level of dependency with the result of internal audits effectiveness and whether it positively moderates the internal-external audit linkages- (vice-versa)" which is the dependent variable, and four independent variables which are "Internalexternal audit linkages", "Independence of internal audit", "audit professionalism "and "Management's support". Consequently, four research hypotheses were developed for each one of the independent variables. Multiple regression analysis was performed to estimate the magnitude of the effect of the "Internal-external audit linkages", "Independence of internal audit" ", "audit professionalism" and "Management's support" on "Management's level of reliance on internal audit work and its impact on the internal-external audit linkages".

To begin with, excluding questions about demographic characteristics, factor analysis based on principal component analysis was used for relevant questions. Varimax orthogonal rotation has been used for the interpretation of the results. Bartlett's Test of Sphericity, at 0.01, has been utilized to identify sufficient correlations between the variables. To determine the adequacy of sampling,Kaser-Meyer-Olkin measure has been put in use (Bryman \& Cramer, 2005). In the end, regression analysis has been utilized. The ordinary least squres(OLS) regression model was:

IIMIE IEL = a + b1 IAL +b2IIA+ b3AP+ b4MS + ei

The variables are defined below:

IIMIE IEL = Interactions of internal audit with management's level of dependency with the result of internal audits effectiveness and whether it positively moderates the internal-external audit linkages- (vice-versa)

IEL = Internal-external audit linkages

IIA = Independence of internal audit

$\mathbf{A P}=$ Audit professionalism

MS = Management's support 


\section{RESULTS AND Discussion}

Demographic characteristics of the respondents which were basically important for this study were age, educational level, work experience and sector of the participants are presented in table 1.

It can be seen in table 1 that the highest percentage is $57.1 \%$ (31-40 years old ) while the lowest percentage is $7.2 \%$ (older than 50 ). Taking educational qualification into consideration, it can be stated that $78.7 \%$ earned BA/BSC degree whereas $21.4 \%$ got a postgraduate degree. Coming to work experience, it is noted that $71.4 \%$ have more than 10 years experience. At last, the percentage for workers involved in the private sector stands as $64.3 \%$ while for those engaged in public sector stands as $35.7 \%$

A total of 100 questionnaires were distributed and 70 properly filled questionnaires were able to be collected back. So a total of 70 questionnaire responses were analyzed. 45 respondents were private employees (Includes private business companies and private audit firms) and 25 were from public firms (Includes public business companies and public audit firms). From the table, the mean for the work experience is 11.23 years, with a median of 8 years. For individual experiences the range is 6 more than 20 years. In terms of specialization, $30 \%$ of the respondents were audit managers, $59 \%$ were senior auditors and $11 \%$ were top managers.

Table 1. Professional demographics of the participants

\begin{tabular}{|l|c|c|c|}
\hline \hline & & Frequency & Percent \\
\hline \hline \multirow{2}{*}{ Age } & $<30$ & 0 & 57.1 \\
& $31-40$ & 40 & 35.7 \\
& $41-50$ & 25 & 7.2 \\
\hline \multirow{2}{*}{ Level of education } & $>50$ & 5 & 78.6 \\
& University-BA/BSC & 55 & 21.4 \\
\hline \multirow{2}{*}{ Work Experience } & Postgraduate & 15 & 7.1 \\
& $<5$ & 0 & 71.4 \\
& $10-20$ & 5 & 21.5 \\
\hline \multirow{2}{*}{ Sector } & $>20$ & 50 & 64.3 \\
& Private & 15 & 35.7 \\
\hline \hline
\end{tabular}




\section{DESCRIPTIVE STATISTICS}

Regarding interactions of internal audit with the management depends on the level of the result of internal audits effectiveness, as the result, this positively moderates the internal-external audit linkages, it can be concluded from this that all of the respondents consider that internal audits effectiveness increases the interaction of internal audit with the management, as the result, it positively moderates the internal-external audit linkages. To better highlight the results, we shall have a closer look at table 2 .

Table 2. Statements regarding interactions of internal audit with management's depend on every level of the result of the internal audits effectiveness and this in return positively moderates the internal-external audit linkages

\begin{tabular}{|c|c|c|c|c|c|}
\hline & \multicolumn{5}{|c|}{ Frequency Percent } \\
\hline & 1 & 2 & 3 & 4 & 5 \\
\hline $\begin{array}{l}\text { Depends on the level of internal audit work ensuring that it } \\
\text { adds value to the business }\end{array}$ & - & - & - & - & $\begin{array}{r}8 \\
100\end{array}$ \\
\hline $\begin{array}{l}\text { Depends on the level of how much internal audit work impro- } \\
\text { ves department's performance }\end{array}$ & - & - & - & - & $\begin{array}{r}8 \\
100\end{array}$ \\
\hline $\begin{array}{l}\text { Depends on the level of how much internal audit work impro- } \\
\text { ves organizational performance }\end{array}$ & - & - & - & - & $\begin{array}{r}8 \\
100\end{array}$ \\
\hline Depends on the level of internal audit's report accuracy & - & - & - & - & $\begin{array}{r}8 \\
100\end{array}$ \\
\hline Depends on the level of internal audit's findings justifiability & - & - & - & - & $\begin{array}{r}8 \\
100\end{array}$ \\
\hline $\begin{array}{l}\text { Depends on the level of internal audit's recommendations } \\
\text { easy implementations. }\end{array}$ & - & - & - & - & $\begin{array}{r}8 \\
100\end{array}$ \\
\hline Depends on the level of internal audits report accuracy & - & - & - & - & $\begin{array}{r}8 \\
100\end{array}$ \\
\hline $\begin{array}{l}\text { External auditor reliance on internal audit depends on the } \\
\text { acceptance of internal audit recommendations by the mana- } \\
\text { gement. }\end{array}$ & - & - & - & - & $\begin{array}{r}8 \\
100\end{array}$ \\
\hline $\begin{array}{l}\text { External auditors reliance on internal audit work is influenced } \\
\text { by the management's acceptance and implementation of } \\
\text { internal audit findings and recommendations. }\end{array}$ & - & - & - & - & $\begin{array}{r}8 \\
100\end{array}$ \\
\hline
\end{tabular}

S o u r c e : author's construction. 
The internal-external audit linkages, analysis results that reveal external audit's recommendations, report, sharing of work papers between internal and external auditors, coordination and collaboration between internal and external auditors for relations between these two groups improve the interactions of internal audit with the management and this in turn positively moderates the internal-external audit linkages- (vice-versa). However, from the results, it is suggested that management's promotions for relations between these two groups is the least rated item. Competence of internal audit team is also highly rated. The results are presented in detail in table 3 below.

Table 3. Statements regarding internal-external audit linkages

\begin{tabular}{|c|c|c|c|c|c|}
\hline & \multicolumn{5}{|c|}{ Frequency Percent } \\
\hline & 1 & 2 & 3 & 4 & 5 \\
\hline $\begin{array}{l}\text { External auditors make recommendations that help improve } \\
\text { internal audit }\end{array}$ & & & 12 & $\begin{array}{l}12 \\
0.4\end{array}$ & $\begin{array}{l}6 \\
0.2\end{array}$ \\
\hline $\begin{array}{l}\text { External audit reports help enhance management's acceptance } \\
\text { of internal audit findings. }\end{array}$ & & & $\begin{array}{r}3 \\
10\end{array}$ & $\begin{array}{l}22 \\
70\end{array}$ & $\begin{array}{r}6 \\
20\end{array}$ \\
\hline $\begin{array}{l}\text { Internal audit follows up implementation of external auditors' } \\
\text { recommendations on improvement of internal control system }\end{array}$ & & & $\begin{array}{r}6 \\
20\end{array}$ & $\begin{array}{l}16 \\
50\end{array}$ & $\begin{array}{r}9 \\
30\end{array}$ \\
\hline $\begin{array}{l}\text { External auditors use internal audit reports in conducting their } \\
\text { audit. }\end{array}$ & & $\begin{array}{r}3 \\
10\end{array}$ & $\begin{array}{l}16 \\
50\end{array}$ & $\begin{array}{r}3 \\
10\end{array}$ & $\begin{array}{r}9 \\
30\end{array}$ \\
\hline $\begin{array}{l}\text { There is frequency of meetings and sharing of work papers } \\
\text { between internal and external auditors }\end{array}$ & & $\begin{array}{r}3 \\
10\end{array}$ & $\begin{array}{l}12 \\
40\end{array}$ & $\begin{array}{r}9 \\
30\end{array}$ & $\begin{array}{r}6 \\
20\end{array}$ \\
\hline $\begin{array}{l}\text { Coordination and collaboration between internal and external } \\
\text { auditors influence the effectiveness }\end{array}$ & & & $\begin{array}{r}3 \\
10\end{array}$ & $\begin{array}{r}9 \\
30\end{array}$ & $\begin{array}{l}19 \\
60\end{array}$ \\
\hline $\begin{array}{l}\text { Management's promotions for relations between these two } \\
\text { groups }\end{array}$ & $\begin{array}{r}3 \\
10\end{array}$ & $\begin{array}{r}3 \\
10\end{array}$ & $\begin{array}{l}12 \\
40\end{array}$ & $\begin{array}{l}12 \\
40\end{array}$ & \\
\hline
\end{tabular}

S o u r c e : author's construction.

Much of the argument obtained from the data asserts that internal auditors are open- minded, accommodating, knowledgeable and, therefore, professional. As a result, it improves the interactions of internal audit with management's because of internal audits effectiveness and positively moderating the internalexternal audit linkages. However, the analysis indicates that internal audit has to have policies for hiring internal audit staff. To better highlight the results, we shall have a closer look at (table 4). 
Table 4. Statements regarding professionalism of internal audit

\begin{tabular}{|c|c|c|c|c|c|}
\hline & \multicolumn{5}{|c|}{ Frequency Percent } \\
\hline & 1 & 2 & 3 & 4 & 5 \\
\hline The internal audit department has enough work space. & & $\begin{array}{c}5 \\
16.1\end{array}$ & $\begin{array}{c}6 \\
19.4\end{array}$ & $\begin{array}{l}17 \\
54.8\end{array}$ & $\begin{array}{l}3 \\
9.7\end{array}$ \\
\hline The Internal audit obtains sufficient budget. & & $\begin{array}{c}4 \\
12.9\end{array}$ & $\begin{array}{l}3 \\
9.7\end{array}$ & $\begin{array}{l}14 \\
51.6\end{array}$ & $\begin{array}{c}8 \\
25.8\end{array}$ \\
\hline $\begin{array}{l}\text { Internal auditors are experienced enough for the organization's } \\
\text { systems. }\end{array}$ & $\begin{array}{l}2 \\
6.5\end{array}$ & $\begin{array}{l}3 \\
9.7\end{array}$ & $\begin{array}{c}6 \\
19.4\end{array}$ & $\begin{array}{l}17 \\
54.8\end{array}$ & $\begin{array}{l}3 \\
9.7\end{array}$ \\
\hline $\begin{array}{l}\text { The internal auditors acquire knowledge and skills beyond acco- } \\
\text { unting and finance as needed. }\end{array}$ & $\begin{array}{l}2 \\
6.5\end{array}$ & $\begin{array}{l}1 \\
3.2\end{array}$ & $\begin{array}{c}5 \\
16.1\end{array}$ & $\begin{array}{l}16 \\
51.6\end{array}$ & $\begin{array}{c}6 \\
19.4\end{array}$ \\
\hline The internal audit has in- house policies for recruiting new staff. & $\begin{array}{c}7 \\
22.6\end{array}$ & $\begin{array}{c}5 \\
16.1\end{array}$ & $\begin{array}{r}9 \\
29\end{array}$ & $\begin{array}{c}6 \\
19.4\end{array}$ & $\begin{array}{c}4 \\
12.9\end{array}$ \\
\hline $\begin{array}{l}\text { The internal auditors are exposed to continuous professional } \\
\text { development activities. }\end{array}$ & $\begin{array}{c}5 \\
16.1\end{array}$ & $\begin{array}{c}4 \\
12.9\end{array}$ & $\begin{array}{l}10 \\
32.3\end{array}$ & $\begin{array}{l}10 \\
32.3\end{array}$ & $\begin{array}{l}2 \\
6.5\end{array}$ \\
\hline $\begin{array}{l}\text { The internal auditors are made to access short-term training } \\
\text { each year. }\end{array}$ & $\begin{array}{l}3 \\
9.7\end{array}$ & $\begin{array}{c}8 \\
25.8\end{array}$ & $\begin{array}{c}7 \\
22.6\end{array}$ & $\begin{array}{r}9 \\
29\end{array}$ & $\begin{array}{l}3 \\
9.7\end{array}$ \\
\hline $\begin{array}{l}\text { The internal auditors are made to access self-contained internal } \\
\text { audit manual or guide. }\end{array}$ & $\begin{array}{l}1 \\
3.2\end{array}$ & $\begin{array}{c}4 \\
12.9\end{array}$ & $\begin{array}{c}4 \\
12.9\end{array}$ & $\begin{array}{l}15 \\
48.4\end{array}$ & $\begin{array}{c}7 \\
22.6\end{array}$ \\
\hline
\end{tabular}

S o u r c e : author's construction.

Respondents also express their opinion on independence and objectivity of internal audit. The analysis of the results reveals that internal auditors have independence and objectivity of internal audit in their work in the organization. However, internal audit ought to participate in audit of activities for the operation of which they were responsible for in the company's processes. To better highlight the results, we shall have a closer look at table 5. 
11. The PERSPECTIVE OF CORPORATE GOVERNANCE...

Table 5. Statements regarding independence and objectivity of internal audit

\begin{tabular}{|l|c|c|c|c|c|}
\hline \hline & \multicolumn{4}{|c|}{ Frequency Percent } \\
\hline \hline & 1 & 2 & 3 & 4 & 5 \\
\hline \hline The internal audit has the freedom to work without intervention. & 1 & 1 & 5 & 16 & 7 \\
& 3.2 & 3.2 & 16.1 & 51.6 & 22.6 \\
\hline The internal audit has the freedom to include their findings in & 1 & 1 & 3 & 20 & 6 \\
audit report. & 3.2 & 3.2 & 9.7 & 64.5 & 19.4 \\
\hline The internal audit reports to the board of directors (or audit & 2 & 2 & 2 & 11 & 14 \\
committee) & 6.5 & 6.5 & 6.5 & 35.5 & 45.2 \\
\hline The managment (or audit committee) oversees employment & 3 & 5 & 12 & 7 & 4 \\
decisions in internal audit. & 9.7 & 16.1 & 38.7 & 22.6 & 12.9 \\
\hline The internal auditors are not given the duty to audit the design \\
of the system in which they participate.
\end{tabular}

S o u r c e : author's construction.

Finally, as per the examination of the management's support, the results show that the management had better make more support reach the internal audit. The analysis of the results also reveals top management's support positively moderates organizational independence towards the effectiveness of internal audits, audit professionalism towards internal audit activities and moderates the effect of the auditees perception towards. Along this line, the senior management, as it can be seen in table 6 , should be more aware of internal audit's needs. 
Table 6. Statements regarding management's support

\begin{tabular}{|c|c|c|c|c|c|}
\hline & \multicolumn{5}{|c|}{ Frequency Percent } \\
\hline & 1 & 2 & 3 & 4 & 5 \\
\hline $\begin{array}{l}\text { Senior management supports internal audit's personnel (recru- } \\
\text { its skillful staff, offers career development chances, provides } \\
\text { independence in the organizations ) }\end{array}$ & $\begin{array}{c}5 \\
16.1\end{array}$ & $\begin{array}{c}5 \\
16.1\end{array}$ & $\begin{array}{r}9 \\
29\end{array}$ & $\begin{array}{c}8 \\
25.8\end{array}$ & $\begin{array}{c}4 \\
12.9\end{array}$ \\
\hline Senior management is aware of internal audit's needs & $\begin{array}{l}1 \\
3.2\end{array}$ & $\begin{array}{c}4 \\
12.9\end{array}$ & $\begin{array}{r}9 \\
29\end{array}$ & $\begin{array}{l}14 \\
45.2\end{array}$ & $\begin{array}{l}3 \\
9.7\end{array}$ \\
\hline $\begin{array}{l}\text { Top management support brings about independence, profes- } \\
\text { sionalism, positive perception about the organization's work and } \\
\text { this in return brings effectiveness. }\end{array}$ & $\begin{array}{l}2 \\
6.5\end{array}$ & $\begin{array}{l}3 \\
9.7\end{array}$ & $\begin{array}{l}14 \\
45.2\end{array}$ & $\begin{array}{l}10 \\
32.2\end{array}$ & $\begin{array}{l}2 \\
6.5\end{array}$ \\
\hline $\begin{array}{l}\text { External auditor's reliance on internal audit is governed by the } \\
\text { acceptance of internal audit recommendations by the manage- } \\
\text { ment. }\end{array}$ & $\begin{array}{l}1 \\
3.2\end{array}$ & $\begin{array}{c}4 \\
12.9\end{array}$ & $\begin{array}{l}11 \\
35.5\end{array}$ & $\begin{array}{l}10 \\
32.3\end{array}$ & $\begin{array}{c}4 \\
12.9\end{array}$ \\
\hline $\begin{array}{l}\text { Management acceptance and implementation of internal audit } \\
\text { findings and recommendations may impact on external auditors' } \\
\text { reliance on internal audit work. }\end{array}$ & $\begin{array}{l}2 \\
6.5\end{array}$ & $\begin{array}{l}3 \\
9.7\end{array}$ & $\begin{array}{c}8 \\
25.8\end{array}$ & $\begin{array}{l}14 \\
45.2\end{array}$ & $\begin{array}{l}3 \\
9.7\end{array}$ \\
\hline
\end{tabular}

S o u r c e : author's construction.

\section{FACTOR ANALYSIS}

The factor analysis, of which the results obtained are stated in table 7, is used in this study as it is one of the most well -known methods of classical multivariate analysis (Tabachnick \& Fidell, 2001). Based on the table, it can be seen that Kaiser-Meyer-Olkin (KMO) scale is figured out as higher than 0.5. Also, each of the five variables can be taken as single measures, ending up with just one component. Moreover, employing Cronbach's alpha of 0.70 or more is accepted as highly reliable and, therefore, the results depict a great internal consistency for the five variables (Nunnally, 1978). In this respect, table 7 shows that Cronbach's alpha for "Statements regarding Interactions of internal audit with management's depends on the level result of internal audits effectiveness and this in turn positively moderates the internal-external audit linkages" is of the 0.9161, for "Internal-external audit linkages" 0.837 , for "Professionalism of Internal Audit" is 0.698, for "Independence and Objectivity of Internal Audit" is 0.916 and for "Management's support" is 0.929 . 
Table 7. Factor analysis

\begin{tabular}{|c|c|c|c|c|}
\hline Factor & Variables & $\begin{array}{l}\text { Cronbach's } \\
\text { Alpha }\end{array}$ & KMO & $\begin{array}{l}\text { Factor } \\
\text { Lodgings }\end{array}$ \\
\hline \multirow{9}{*}{$\begin{array}{l}\text { Statements regarding } \\
\text { Interactions of internal } \\
\text { audit with managemen- } \\
\text { t's depending on the } \\
\text { level of the result of } \\
\text { internal audits effecti- } \\
\text { veness and in return it } \\
\text { positively moderates } \\
\text { the internal-external } \\
\text { audit linkages(vice- } \\
\text {-versa) }\end{array}$} & $\begin{array}{l}\text { Depends on the level of internal audit work ensu- } \\
\text { ring that it adds value to the business }\end{array}$ & \multirow[t]{9}{*}{0.9161} & \multirow[t]{9}{*}{0.9045} & 0.812 \\
\hline & $\begin{array}{l}\text { Depends on the level of how much internal audit } \\
\text { work improves department's performance }\end{array}$ & & & 0.919 \\
\hline & $\begin{array}{l}\text { Depends on how much internal audit work impro- } \\
\text { ves organizational performance }\end{array}$ & & & 0.875 \\
\hline & $\begin{array}{l}\text { Depends on the level of internal audit's report } \\
\text { accuracy }\end{array}$ & & & 0.869 \\
\hline & $\begin{array}{l}\text { Depends on the level of internal audit's findings } \\
\text { justifiability }\end{array}$ & & & 0.927 \\
\hline & $\begin{array}{l}\text { Depends on the level of internal audit's recom- } \\
\text { mendations to be easily implemented }\end{array}$ & & & 0.903 \\
\hline & $\begin{array}{l}\text { Depends on the level of internal audits report } \\
\text { accuracy }\end{array}$ & & & 0.773 \\
\hline & $\begin{array}{l}\text { External auditor reliance on internal audit is } \\
\text { influenced by the acceptance of internal audit } \\
\text { recommendations by the management. }\end{array}$ & & & 0.914 \\
\hline & $\begin{array}{l}\text { External auditors dependency on internal audit } \\
\text { work is highly affected by the acceptance and } \\
\text { implementation of internal audit findings and } \\
\text { recommendations. }\end{array}$ & & & 0.789 \\
\hline \multirow{6}{*}{$\begin{array}{l}\text { Statements regarding } \\
\text { Internal-external audit } \\
\text { linkages }\end{array}$} & $\begin{array}{l}\text { External auditor's recommendations may improve } \\
\text { internal audit. }\end{array}$ & \multirow[t]{6}{*}{0.837} & \multirow[t]{6}{*}{0.735} & 0.869 \\
\hline & $\begin{array}{l}\text { External audit reports empowers managements } \\
\text { to accept internal audit findings. }\end{array}$ & & & 0.927 \\
\hline & $\begin{array}{l}\text { Internal audit does a follow up of the imple- } \\
\text { mentation of external auditors' improvement of } \\
\text { internal control system recommendations. }\end{array}$ & & & 0.903 \\
\hline & $\begin{array}{l}\text { External auditors make use of internal audit } \\
\text { reports in conducting their audit. }\end{array}$ & & & 0.773 \\
\hline & $\begin{array}{l}\text { External -internal auditors coordination and } \\
\text { collaboration influences effectiveness. }\end{array}$ & & & 0.914 \\
\hline & $\begin{array}{l}\text { Management promotes and advocates for rela- } \\
\text { tions between external -internal auditors. }\end{array}$ & & & 0.789 \\
\hline
\end{tabular}


Table 7. Factor...

\begin{tabular}{|c|c|c|c|c|}
\hline Factor & Variables & $\begin{array}{l}\text { Cronbach's } \\
\text { Alpha }\end{array}$ & KMO & $\begin{array}{l}\text { Factor } \\
\text { Lodgings }\end{array}$ \\
\hline \multirow[t]{8}{*}{$\begin{array}{l}\text { Professionalism of } \\
\text { Internal Audit }\end{array}$} & $\begin{array}{l}\text { The internal audit department has enough work } \\
\text { space. }\end{array}$ & \multirow[t]{8}{*}{0.698} & \multirow[t]{8}{*}{0.806} & 0.876 \\
\hline & The Internal audit obtains sufficient budget. & & & 0.841 \\
\hline & $\begin{array}{l}\text { Internal auditors are experienced enough for the } \\
\text { organization's systems. }\end{array}$ & & & 0.872 \\
\hline & $\begin{array}{l}\text { The internal auditors acquire knowledge and skills } \\
\text { beyond accounting and finance as needed. }\end{array}$ & & & 0.817 \\
\hline & $\begin{array}{l}\text { The internal audit has in- house policies for recru- } \\
\text { iting new staff. }\end{array}$ & & & 0.419 \\
\hline & $\begin{array}{l}\text { The internal auditors are exposed to continuous } \\
\text { professional development activities. }\end{array}$ & & & 0.825 \\
\hline & $\begin{array}{l}\text { The internal auditors are made to access short - } \\
\text { term training each year. }\end{array}$ & & & 0.498 \\
\hline & $\begin{array}{l}\text { The internal auditors are made to access self-con- } \\
\text { tained internal audit manual or guide. }\end{array}$ & & & 0.810 \\
\hline \multirow{7}{*}{$\begin{array}{l}\text { Statements regarding } \\
\text { Independence and } \\
\text { Objectivity of Internal } \\
\text { Audit }\end{array}$} & $\begin{array}{l}\text { Internal audit is free from intervention in perfor- } \\
\text { ming its duties }\end{array}$ & \multirow[t]{7}{*}{0.916} & \multirow[t]{7}{*}{0.890} & 0.932 \\
\hline & $\begin{array}{l}\text { Internal auditors feel free to include any audit } \\
\text { findings in their audit reports }\end{array}$ & & & 0.879 \\
\hline & $\begin{array}{l}\text { Internal audit provides reports to the manage- } \\
\text { ment of directors (or audit committee) }\end{array}$ & & & 0.788 \\
\hline & $\begin{array}{l}\text { The managment (or audit committee) oversees } \\
\text { employment decisions in internal audit }\end{array}$ & & & 0.835 \\
\hline & $\begin{array}{l}\text { Internal auditors are not assigned to audit areas } \\
\text { in the system design which they participated }\end{array}$ & & & 0.809 \\
\hline & $\begin{array}{l}\text { Internal auditors do not participate in audit of } \\
\text { activities for the operation of which they were } \\
\text { responsible }\end{array}$ & & & 0.910 \\
\hline & $\begin{array}{l}\text { Internal audit staff assignments are rotated } \\
\text { periodically }\end{array}$ & & & 0.877 \\
\hline
\end{tabular}


Table 7. Factor...

\begin{tabular}{|c|c|c|c|c|}
\hline Factor & Variables & $\begin{array}{l}\text { Cronbach's } \\
\text { Alpha }\end{array}$ & KMO & $\begin{array}{l}\text { Factor } \\
\text { Lodgings }\end{array}$ \\
\hline \multirow[t]{5}{*}{ Management's support } & $\begin{array}{l}\text { Senior management supports internal audit's } \\
\text { personnel(Employing skillful internal audit staff, } \\
\text { developing career paths for internal audit staff, } \\
\text { and providing organizational independence for } \\
\text { internal audit works) }\end{array}$ & \multirow[t]{5}{*}{0.929} & \multirow[t]{5}{*}{0.896} & 0.932 \\
\hline & $\begin{array}{l}\text { Senior management's is aware of internal audit's } \\
\text { needs }\end{array}$ & & & 0.795 \\
\hline & $\begin{array}{l}\text { Top management's support positively moderates } \\
\text { organizational independence towards the effec- } \\
\text { tiveness of internal audits, audit professionalism } \\
\text { towards internal audit activities and moderates } \\
\text { the effect of the auditee's perception towards. }\end{array}$ & & & 0.808 \\
\hline & $\begin{array}{l}\text { External auditor's reliance on internal audit is } \\
\text { governed by the acceptance of internal audit } \\
\text { recommendations by the management. }\end{array}$ & & & 0.928 \\
\hline & $\begin{array}{l}\text { External auditor's reliance on internal audit work } \\
\text { is influenced by the management's acceptance } \\
\text { and implementation of internal audit findings and } \\
\text { recommendations. }\end{array}$ & & & 0.913 \\
\hline
\end{tabular}

S o u r c e : author's construction.

\section{REGRESSION ANALYSIS}

As it can be observed in table 8, for dependent and independent variables, a Pearson correlation matrix is employed. It is found that there is a determining and positive correlation ( $\mathrm{r}=-.0891$ ) between "Interactions of internal audit with management's dependency on the level of the result of internal audits effectiveness and in turn it positively moderates the internal-external audit linkages (vice-versa)" and "Internal-external audit linkages" at $\mathrm{p}<.05$. In the meantime, there is a positive relationship between "Interactions of internal audit with management's dependency on the level of the result of the internal audits effectiveness and in return this positively moderates the internal-external audit linkages" and "Independence of internal audit" (b1=0.193, p=0.006). Thus, $\mathrm{H} 1$ is strongly supported. Similar but even more intensive, there is a positive relationship between "Interactions of internal audit with management's depend level result of internal audits effectiveness and toward positively moderates the internal-external audit linkages" and "audit professionalism" (b3=0.302, 
$\mathrm{p}=0.041$ ), suggesting support for $\mathrm{H} 2$. The third hypothesis relates to management's support. In this case, the regression analysis revealed a positive and high association ( $\mathrm{b} 4=0.229, \mathrm{p}=0.003$ ) between "management's support" and Interactions of internal audit with management's dependency on the level of results of the internal audit's effectiveness" and this, in return, positively moderate the internal-external audit linkages." Thus, H3 is strongly supported.

Table 8. Correlation matrix

\begin{tabular}{|l|c|c|c|c|c|}
\hline \hline & IIMIE IEL & IEL & IIA & AP & MS \\
\hline \hline IIMIE IEL & 1 & & & & \\
\hline IEL & $0.891^{* *}$ & 1 & & & \\
\hline IIA & $0.789^{*}$ & $0.747^{*}$ & 1 & & 1 \\
\hline AP & $0.882^{*}$ & $0.829^{*}$ & $0.714^{* *}$ & 0.512 & 1 \\
\hline MS & $0.816^{*}$ & $0.81^{*}$ & $0.913^{*}$ & 0 & \\
\hline \hline
\end{tabular}

** : significant Pearson Correlation (positive)

* : signficant Pearsons correlation (negative)

S o u r c e : author's construction.

Table 9. Regression analysis

\begin{tabular}{|c|c|c|c|c|c|}
\hline Variables & Coeff. $_{0}$ & Value & S.E. & $\mathbf{T}$ & p-Value \\
\hline Constant & $b_{0}$ & 1.621 & 0.467 & 2.91 & $0.003^{*}$ \\
\hline IEL & $b_{1}$ & 0.193 & 0.039 & 2.567 & $0.006^{*}$ \\
\hline IIA & $b_{b 2}$ & 0.096 & 0.031 & 1.392 & $0.073^{* *}$ \\
\hline AP & $b_{3}$ & 0.302 & 0.161 & 2.93 & $0.041^{*}$ \\
\hline MS & $b_{4}$ & 0.229 & 0.033 & 4.109 & $0.003^{*}$ \\
\hline \multicolumn{6}{|c|}{$*^{*}$ significant at 0.05 level; ${ }^{* *}$ : significant at 0.1 level } \\
\hline $\mathrm{R}^{2}$ & $=0.817$ & & & & \\
\hline Adjusted $\mathrm{R}^{2}$ & $=0.802$ & & & & \\
\hline \multicolumn{6}{|l|}{$F=146.149$} \\
\hline$p=0.0012$ & & & & & \\
\hline
\end{tabular}

S o u r c e : author's construction. 


\section{ConCLUSION}

This study has examined the interactions of internal audit with management and its impact on the internal-external audit linkages in developing countries. This thorough analysis supports the interactions of internal audit with management has a positively significant impact on the internal-external audit linkages in developing countries. In the meantime the paper has attempted to find out whether the independent variables, that is, internal- external audit linkages, independence of the internal audit, audit professionalism and management support, contribute toward these interactions and linkages. From the study, it is identified that these variables directly or indirectly have a positively significant impact for the interactions of internal audit with the management and this in turn positively moderates the internal- external audit linkages and vice-versa.

In general, the outcomes of this research are expected to offer practical and theoretical contribution to concerned users. Frist, the result may illuminate how interactions of internal audit with management have a positively significant impact on the internal-external audit linkage in Ethiopia. This may inform top management of organizations in the assessment of internal audit department performance. Second, international bodies concerned in the area and realities in developing countries might be tipped off as to how interactions of internal audit with management have a significant, positive influence on the internal-external audit linkages.

The data collected by the survey was limited on purpose to restrict the length of the questionnaire and to maximize response rates. Besides, the data gathered is collected from the management, internal and external auditors excluding other stakeholders such as board of directors and shareholders. Hence, this requires a further study to be carried out to investigate and incorporate the perception of these parties. Concerning the data calculation, other alternative independent variables could be modelled.

Eventually, it is suggested that other complimentary data gathering tools such as interview could be exploited to further investigate the extent to which internal-external linkage in Ethiopia are positively and significantly influenced by the interactions of internal audit with management . 


\section{REFERENCES}

Adams, M. (1994). Agency hypothesis and the internal audit. Managerial Auditing Journal, 9(8), 8-12.

Allegrini, M., D’Onza, G., Paape, L., Melville, R., \& Sarens, G. (2006). The European literature review on internal auditing. Managerial Auditing Journal, 21(8), 845-853.

Alleyne, P. A., \& Devonish, D. (2006). Perceptions of Auditor Independence in Barbados. Managerial Auditing Journal, 21(6), 621-635.

Al-Twaijry, A.A.M., Brierley, J.A., \& Gwilliam, D.R. (2004). An examination of the relationship between internal and external audit in the Saudi Arabian corporate sector. Managerial Auditing Journal, 19, 929-944. http://dx.doi.org/10.1108/02686900410549448.

Alzeban, A., \& Gwilliam, D. (2014). Factors Affecting the Internal Audit Effectiveness: A Survey of the Saudi Public Sector. Journal of International Accounting, Auditing and Taxation, 23(2), 74-86.

Arens, A.A., Elder, R.J., \& Beasley, M.S. (2011). Auditing dan Pelayanan Verifikasi: Pendekatan Terpadu, alih bahasa oleh Tim Dejakarta, edisi kesembilan. Jakarta: Indeks.

Badara, M.A.S., \& Saidin, S.Z. (2014). Empirical Evidence of Antecedents of Internal Audit Effectiveness from Nigerian Perspective. Middle-East Journal of Scientific Research, 19(4), 460-469.

Badara, M.S. (2015). Empirical Evidence of Performance Measurement of Internal Audit Function onits Effectiveness. Academic Journal of Management Science Research, 1(1), 1-10.

Bota-Avram, C., \& Palfi, C. (2009). Measuring And Assessment Of Internal Audit'S Effectiveness. Annals of Faculty of Economics, University of Oradea, Faculty of Economics, 3(1), 784-790.

Bradburn, N.M., Sudman, S., \& Wansink, B. (2004). Asking Questions. San Francisco: Jossey-Bass.

Bryman, A., \& Cramer, D. (2005). Quantitative Data Analysis with SPSS 12 and 13: A Guide for Social Scientists. Sussex: Psychology Press.

Carcello, J.V., Hermanson, D.R., \& Raghunandan, K. (2005). Factors associated with US public companies' investment in internal auditing. Accounting Horizons, 19(2), 69-84.

Cohen, A., \& Sayag, G. (2010). The Effectiveness of Internal Auditing: An Empirical Examination of its Determinants in Israeli Organisations. Australian Accounting Auditors, 20(3), 296-307. http://dx.doi.org/10.1111/j.1835-2561.2010.00092.x.

Endaya, K.A., \& Hanefah, M.M. (2013). Internal Audit Effectiveness: An Approach Proposition to Develop the Theoretical Framework. Research Journal of Finance and Accounting, 4(10), 92-102.

Felix, W.L., Gramling, A.A., \& Maletta, M.J. (1998). Coordinating Total Audit Coverage: The Relationship between Internal and External Auditors. Altamonte Springs, FL: Institute of Internal Auditors. 
Felix, W.L.J., Gramling, A.A. \& Maletta, M.J. (2001). The Contribution of Internal Audit as a Determinant of External Audit Fees and Factors Influencing this Contribution. Journal of Accounting Research, 39(3), 513-534.

George, D., Theofanis, K., \& Konstantinos, A. (2015). Factors Associated with Internal Audit Effectiveness: Evidence from Greece. Journal of Accounting and Taxation, 7(7), 113-122. http://dx.doi.org/10.5897/JAT2015.0182.

Gramling, A.A, Maletta, M., Schneider, A., \& Church, B. (2004). The role of the internal audit function in corporate governance: a synthesis of the extant internal auditing literature and directions for future research. Journal of Accounting Literature, (23)1, 194-244.

Holm, C., \& Laursen, P.B. (2007). Risk and Control Developments in Corporate Governance: changing the role of the external auditor?, Corporate Governance: An International Review, Wiley Blackwell, 15(2), 322-333.

Kandelousi, N.S. (2011). Key Success Factors for Managing Projects. World Academy of Science, Engineering and Technology. International Journal of Social, Behavioral, Educational, Economic, Business and Industrial Engineering, 5(11), 1541-1545.

Maletta, M.J. (1993). An Examination of Auditors' Decisions to Use Internal Auditors as Assistants: The Effect of Inherent Risk. Contemporary Accounting Research, 9(2), 508-525.

Messier, W.F., Jr., \& Schneider, A. (1988). A hierarchical approach to the external auditor's evaluation of the internal auditing function. Contemporary Accounting Research, 4(2), 337-353. http://dx.doi.org/10.1111/j.1911-3846.1988.tb00670.x.

Mihret, D.G., \& Admassu, M.A. (2011). Reliance of external auditors on internal audit work: A corporate governance perspective. International Business Research, 4(2), 67-79.

Mihret, D.G., \& Woldeyohannis, G.Z. (2008). Value-added role of internal audit: an Ethiopian case study. Managerial Auditing Journal, 23(6), 567-595. http://dx.doi. org/10.1108/02686900810882110.

Mihret, D.G., \& Yismaw, A.W. (2007). Internal Audit Effectiveness: an Ethiopian public sector case study. Managerial Auditing Journal, 22(5), 470-484. .

Moore, W.G., \& Hodgson, D. (1993). The Joint Audit Approach. Internal Auditor, 50 (4).

Nagy, A.L., \& Cenker, W.L. (2002). An assessment of the newly defined internal audit function. Managerial Auditing Journal, 17(3), 130-137.

Nunnally, J.C. (1978). Psychometric Theory, Second Edition. New York: McGraw-Hill. 13. Parasurama.

Oppenheim, A.N. (1992). Questionnaire, design, interviewing and attitude measurement. London: Pinter Pub Ltd.

Renard, J. (2006). Théorie et pratique de l'audit interne. Organisation, France.

Rezaee, Z. (1996). Improving the quality of internal audit functions through total quality management's. Managerial Auditing Journal, 11(1), 30-34. http://dx.doi. org/10.1108/02686909610105584.

Roth, J. (2000). Best Practices: Value-added Approaches of Four Innovative Auditing Departments. Altamonte Springs, FL: Institute of Internal Auditors. 
Rusak, A., \& Johnson, R. (2007). The Responsibilities of Audit Committees. In R. Jonson (Ed.). Readings in Auditing. Australia Ltd, Milton Qld: John Wiley \& Sons.

Sarens, G. (2009). Editorial note - internal auditing research: where are we going? International Journal of Auditing, 13(1), 1-7.

Shohiha, A. (2017). Spesialnya Laporan Dana Zakat Bank Syariah. Dipetik Febrruari 15, 2018, dari Kompasiana. https://www.kompasiana.com/aaqied/ spesialnya-laporan-dana-zakat-bank-syariah_58af3aa6c6afbd961c3ba32f.

Tabachnick, B.G., \& Fidell, L.S. (2001). Using Multivariate Statistics, 4th ed. Boston: Allyn and Bacon.

Tackie, G., Marfo-Yiadom, E., \& Achina, S.O. (2016). Determinants of Internal Audit Effectiveness in Decentralized Local Government Administrative Systems. International Journal of Business and Management, 11(11), 184.

Van Peursem, K.A. (2005). Conversations with Internal Auditors: The Power of Ambiguity. Managerial Auditing Journal, 20(5), 489-512. https://www.transparency.org/ news/feature/corruption_perceptions_index_2017 (accessed: 6.03.2018). 